\title{
Does the nitrogen application associated with Azospirillum brasilense inoculation influence corn nutrition and yield?
}

\author{
Elton M. de Souza ${ }^{1}$, Fernando S. Galindo' ${ }^{2}$, Marcelo C. M. Teixeira Filho ${ }^{2}$, \\ Paulo R. T. da Silva ${ }^{2}$, Arthur C. dos Santos ${ }^{1} \&$ Guilherme C. Fernandes ${ }^{2}$ \\ ${ }^{1}$ Faculdades Integradas de Três Lagoas. Três Lagoas, MS. E-mail: eltonmoreira_souza@hotmail.com - ORCID: 0000-0003-2221-3958; arthur_santos@hotmail.com - \\ ORCID: 0000-0002-7166-5144 \\ ${ }^{2}$ Universidade Estadual Paulista “Júlio de Mesquita Filho"/Faculdade de Engenharia de Ilha Solteira/Departamento de Fitossanidade, Engenharia Rural e Solos. Ilha \\ Solteira, SP. E-mail: fs.galindo@yahoo.com.br (Corresponding author) - ORCID: 0000-0001-5118-7459; mcmtf@yahoo.com.br - ORCID: 0000-0003-2303-3465; \\ pauloteodoro@agronomo.eng.br - ORCID: 0000-0001-6048-3284; guilherme.carlos.fernandes@gmail.com - ORCID: 0000-0002-9346-9873
}

\begin{abstract}
The aim of this study was to investigate the synergistic effect between inoculation with Azospirillum brasilense and nitrogen application, thus enabling a higher efficiency of nitrogen fertilization, as evaluated by nutritional value, components production, and grain yield of irrigated corn. The experiment was conducted in Selvíria, MS, Brazil, under a no-till system, on an Oxisol in the Brazilian Cerrado. The experiment was set up in a randomized block design with four replications, in a $4 \times 2$ factorial arrangement: four patterns of nitrogen application [application of $30 \mathrm{~kg} \mathrm{ha}^{-1}$ of $\mathrm{N}$ at sowing and $150 \mathrm{~kg} \mathrm{ha}^{-1}$ as cover $(30+150)$; $30 \mathrm{~kg} \mathrm{ha}^{-1}$ of $\mathrm{N}$ at sowing, split into two applications of $75 \mathrm{~kg} \mathrm{ha}^{-1}$ as cover $(30+75+75) ; 180 \mathrm{~kg} \mathrm{ha}^{-1} \mathrm{of} \mathrm{N}$ at sowing (180); and $150 \mathrm{~kg} \mathrm{ha}^{-1}$ of $\mathrm{N}$ at sowing and $30 \mathrm{~kg} \mathrm{ha}^{-1}$ as cover (150+30)]; with and without inoculation of the seeds with $A$. brasilense. The application of $30 \mathrm{~kg} \mathrm{ha}^{-1}$ of $\mathrm{N}$ at sowing and a single application of $150 \mathrm{~kg} \mathrm{ha}^{-1}$ or two applications of $75 \mathrm{~kg} \mathrm{ha}^{-1}$ in topdressing, inoculated with Azospirillum brasilense provided better nutrition and development, with a positive reflection on irrigated corn grain yield in the Brazilian Cerrado.
\end{abstract}

Key words: Zea mays, biological nitrogen fixation in grasses, bacteria promoting of plant growth, nitrogen fertilization management

\section{Formas de aplicação de nitrogênio com Azospirillum brasilense inoculado influenciam nutrição e produtividade do milho?}

RESUMO: Objetivou-se neste estudo verificar o efeito sinérgico entre a inoculação com Azospirillum brasilense e formas de aplicação de nitrogênio, possibilitando maior eficiência na adubação nitrogenada, avaliando a nutrição, componentes produtivos e produtividade de grãos de milho irrigado. O experimento foi realizado em Selvíria, MS, Brasil, em sistema plantio direto em um Latossolo Vermelho distrófico textura argilosa em Cerrado Brasileiro. O experimento foi conduzido em blocos casualizados com quatro repetições, em esquema fatorial 4 x 2: quatro formas de aplicação de nitrogênio $\left(30 \mathrm{~kg} \mathrm{ha}^{-1} \mathrm{de} \mathrm{N}\right.$ na semeadura e $150 \mathrm{~kg} \mathrm{ha}^{-1} \mathrm{em}$ cobertura (30 + 150); $30 \mathrm{~kg} \mathrm{ha}^{-1}$ de $\mathrm{N}$ na semeadura e parcelamento em 2 aplicações de $75 \mathrm{~kg} \mathrm{ha}^{-1}$ em cobertura (30 + 75 + 75); $180 \mathrm{~kg} \mathrm{ha}^{-1}$ de N em semeadura (180) e $150 \mathrm{~kg} \mathrm{ha}^{-1} \mathrm{de} \mathrm{N}$ na semeadura e $30 \mathrm{~kg} \mathrm{ha}^{-1}$ em cobertura (150 + 30).); com e sem inoculação das sementes com A. brasilense. A aplicação de $30 \mathrm{~kg} \mathrm{ha}^{-1} \mathrm{de} \mathrm{N}$ em semeadura e $150 \mathrm{~kg} \mathrm{ha}^{-1}$ ou o parcelamento em duas aplicações de $75 \mathrm{~kg} \mathrm{ha}^{-1}$ em cobertura, inoculado com Azospirillum brasilense propiciou melhor nutrição e desenvolvimento, com reflexo positivo na produtividade de grãos de milho irrigado em região de Cerrado Brasileiro.

Palavras-chave: Zea mays, fixação biológica de nitrogênio em gramíneas, bactéria promotora de crescimento de plantas, manejo da adubação nitrogenada 


\section{INTRODUCTION}

To obtain high yields of corn grain, it is necessary to apply high doses of nitrogen $(\mathrm{N})$, because the soil does not have an adequate supply to meet the demand of this crop (Teixeira Filho et al., 2014; Galindo et al., 2016). Nitrogen fertilization is one of the highest costs of the production process of nonleguminous crops (Nunes et al., 2015). Wheat, corn, and rice crops utilize approximately $60 \%$ of the $\mathrm{N}$ fertilizer produced in the world (Espindula et al., 2014). In addition, both nitrogen fertilizer production and application contribute to $\mathrm{CO}_{2}$ and $\mathrm{NO}_{2}$ gases that contribute to an increase in the greenhouse effect on Earth (Xu et al., 2012).

In this context, one possibility for increasing the efficiency of nitrogen fertilization is the use of inoculants containing bacteria that promote growth and increase plant productivity. The technology of inoculation of nonlegumes with nonsymbiotic plant growth-promoting bacteria (PGPB), whose main representative is Azospirillum spp., has been increasingly adopted in several countries, especially for crops such as corn and wheat (Díaz-Zorita \& Fernandez-Canigia, 2009; Hartmann \& Bashan, 2009; Marks et al., 2015). The analysis of results from a large number of field trials with various nonlegume crops, conducted worldwide over 20 years under different soil and weather conditions, has demonstrated that yield can be increased up to $30 \%$ (Fukami et al., 2016, 2017) in response to inoculation with Azospirillum.

Another component that has been studied in order to optimize the management of nitrogen fertilization is the ideal moment to apply this fertilizer. Traditionally, at sowing, annual crops receive only a fraction of the $\mathrm{N}$ required for adequate crop development, and the remaining $\mathrm{N}$ is applied between the rows as a topdressing. This is due to three factors: low initial demand, possibility of leach losses, and the high salt content of nitrogen fertilizers. Currently, the timing of the application is one of the most controversial aspects in the management of nitrogen fertilization of grasses in no-tillage systems with a succession of grasses, since during the first years following adoption of this system, there may be an initial lack of $\mathrm{N}$ due to the immobilization caused by the microbial decomposition of the residues of the predecessor crop (Teixeira Filho et al., 2010). Thus, in some cases, anticipatory nitrogen fertilization, in relation to conventional recommendations, or even in relation to crop sowing, may be more efficient in increasing the yield of annual grain crops (Santos et al., 2010). However, there is a need for further studies, especially for corn crops in regions with dry winters and controlled irrigation.

In the majority of previous studies, both with inoculation with Azospirillum brasilense and with various patterns of application, an increase in corn yield was not observed. In view of above, and due to the lack of information about this interaction, the hypothesis of this study was that there may be a synergic effect between inoculation with $A$. brasilense and the moment and form of application of nitrogen, thus allowing a higher efficiency of nitrogen fertilization. Therefore, the objective of this study was to evaluate the interaction of various patterns and timing of nitrogen application with inoculation with Azospirillum brasilense on the nutritional value, components production, and grain yield of irrigated corn in the Brazilian Cerrado.

\section{Material ANd Methods}

This study was conducted during the crop year of 2016/17, located in Selvíria, MS, Brazil (coordinates $20^{\circ} 22^{\prime} \mathrm{S}, 51^{\circ} 22^{\prime}$ $\mathrm{W}, 335 \mathrm{~m}$ above sea level) in the Education and Research Farm of the Faculdade de Engenharia, Universidade Estadual Paulista (FE/UNESP). The soil of the experimental area was classified as a Latossolo Vermelho distrófico of clayey texture, according to the Brazilian Agricultural Research Corporation (EMBRAPA, 2013), which had been cultivated with annual crops for over 28 years. For the previous 11 years, it was under a no-till system, with crop rotation among corn, beans, rice, and wheat, and prior to that, rotation between corn and common bean. Precipitation, relative humidity of the air, and maximum, average, and minimum temperatures were recorded during the experimental period and are shown in Figure 1.

A randomized-block design with four replications was set up in a $4 \times 2$ factorial arrangement consisting of four patterns of nitrogen application [30 $\mathrm{kg} \mathrm{ha}^{-1}$ of $\mathrm{N}$ at sowing and $150 \mathrm{~kg} \mathrm{ha}^{-1}$

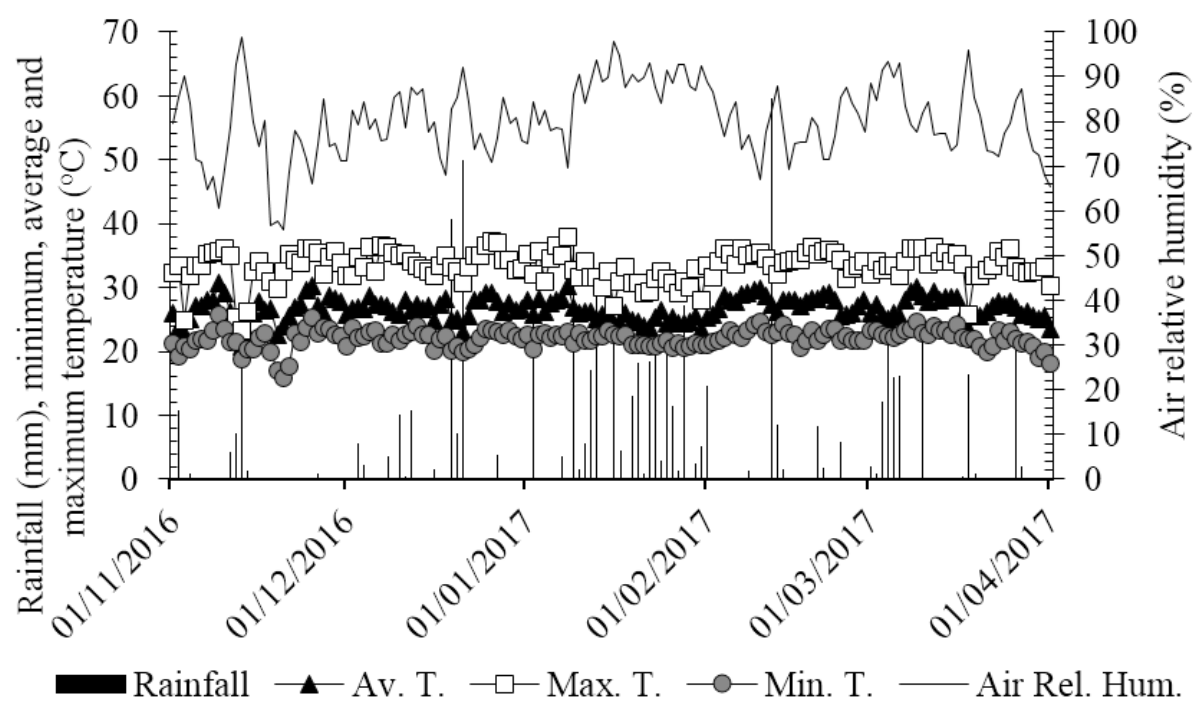

Figure 1. Rainfall, air relative humidity and maximum, average and minimum temperatures obtained from the weather station located in the Education and Research Farm of FE/UNESP during the corn cultivation in the period November 2016 to April 2017 
as cover $(30+150) ; 30 \mathrm{~kg} \mathrm{ha}^{-1}$ of $\mathrm{N}$ at sowing, split into two applications of $75 \mathrm{~kg} \mathrm{ha}^{-1}$ as cover $(30+75+75) ; 180 \mathrm{~kg} \mathrm{ha}^{-1}$ of $\mathrm{N}$ at sowing (180); and $150 \mathrm{~kg} \mathrm{ha}^{-1}$ of $\mathrm{N}$ at sowing and $30 \mathrm{~kg} \mathrm{ha}^{-1}$ as cover $\left.(150+30)\right]$; with and without inoculation of the seeds with $A$. brasilense. The plots were each $5 \mathrm{~m}$ long with six lines separated by $0.45 \mathrm{~m}$, and the plot area comprised the four central rows, excluding the outer $0.5 \mathrm{~m}$.

The herbicides glyphosate $\left[1,800 \mathrm{~g} \mathrm{ha}^{-1}\right.$ of the active ingredient (a.i.)] and 2,4-D (670 $\mathrm{g} \mathrm{ha}^{-1}$ of the a.i.) were used for the desiccation of the agricultural area. The soil chemical attributes in the arable layer were determined before the implementation of the corn experiment in 2016, following the methodology proposed by Raij et al. (2001); see Table 1.

During fertilization at planting, $375 \mathrm{~kg} \mathrm{ha}^{-1}$ of the 8-28-16 formulation were used, corresponding to $30 \mathrm{~kg} \mathrm{ha}^{-1} \mathrm{~N}, 105 \mathrm{~kg} \mathrm{ha}^{-1}$ $\mathrm{P}_{2} \mathrm{O}_{5}$, and $60 \mathrm{~kg} \mathrm{ha}^{-1} \mathrm{~K}_{2} \mathrm{O}$, based on the soil analysis and the requirements of the corn crop. For treatments with 180 and $150 \mathrm{~kg} \mathrm{ha}^{-1}$ at the time of sowing, nitrogen in the form of urea was mixed with the formulation.

The inoculation of corn seeds with the bacterium Azospirillum brasilense strains Ab-V5 Ab-V6 (guarantee of 2 $\mathrm{x} 10^{8} \mathrm{~mL}^{-1} \mathrm{CFU}$ - colony forming unit) was carried out at the dose of $200 \mathrm{~mL}$ of inoculant (liquid) per hectare of sown seeds, with the aid of a clean mixer for inoculant incorporation in the seeds. The inoculation was carried out one hour prior to sowing the crop and after treatment of the seeds with insecticide and fungicide. For seed treatment, the fungicides pyraclostrobin + thiophanate-methyl $(6 \mathrm{~g}+56 \mathrm{~g}$, respectively, of a.i. per 100 $\mathrm{kg}$ of seed) and the insecticide fipronil (62 $\mathrm{g}$ of a.i. per $100 \mathrm{~kg}$ of seed) were used.

The mechanical sowing of the simple hybrid DOW 2B710 PW was carried out on $12 / 10 / 16$, with sowing at a rate of 3.3 seeds $\mathrm{m}^{-1}$; seedlings emerged five days after sowing, on $12 / 15 / 2016$. The corn crop was irrigated using a center-pivot sprinkling system, with a mean water depth of $14 \mathrm{~mm}$ and an irrigation interval of approximately $72 \mathrm{~h}$. On $01 / 02 / 2017$, the herbicides tembotrione ( $84 \mathrm{~g} \mathrm{ha}^{-1}$ of a.i.) and atrazine ( $1000 \mathrm{~g} \mathrm{ha}^{-1}$ of a.i.) were applied for the control of post-emergence weeds, including the addition of an adjuvant in the herbicide syrup, oil ( $720 \mathrm{~g} \mathrm{ha}^{-1}$ of a.i.). Insect control was performed with methomyl (215 $\mathrm{g} \mathrm{ha}^{-1}$ a.i.) and triflumurom (24 $\mathrm{g} \mathrm{ha}^{-1}$ a.i.), on 01/16/2016.

Nitrogen topdressing fertilization (treatments application) was performed between the corn lines on hauls and without soil incorporation on $01 / 14 / 16$, when each plant had six completely unfolded leaves (V6). For the treatment in which the nitrogen fertilization was applied in split (two) cover applications, each of $75 \mathrm{~kg} \mathrm{ha}^{-1}$, the applications were carried out when each plant had four completely unfolded leaves (V4) on 12/30/16 and at V6. The application was done manually, distributing the fertilizer on the soil surface (without incorporation), to the side and approximately $10 \mathrm{~cm}$ of the rows, in order to avoid the contact of the fertilizer (urea source) with the plants.
After cover fertilization, the area was irrigated by sprinkling (depth of $14 \mathrm{~mm}$ ) at night to minimize losses by volatilization of ammonia. The harvest was carried out on $04 / 20 / 2017,125$ days after corn emergence.

The following evaluations were performed:

a) $\mathrm{N}$ foliar concentration, obtained by collecting the middle third of 20 leaves of the main ear insertion, in the female flowering of the corn plants of each plot according to the methodology described in Cantarella et al. (1997);

b) $\mathrm{N}$ concentration in the root and aerial parts in the female flowering and straw, and based on the dry matter yield; $\mathrm{N}$ accumulations were calculated;

c) The leaf chlorophyll index (LCI; dimensionless) was determined indirectly in 10 plants per plot after application of the treatments and when the plants were in the flowering stage; the readings were performed in the leaf below the ear (in the middle third of each leaf);

d) Root and shoot dry matter yield in the female flowering of the corn plants of each plot, evaluated by collecting five plants per plot;

e) Stem diameter of the plant at corn maturation, obtained using a manual pachymeter;

f) plant height, and g) inserting height of the main high spike at maturity, defined as being at a distance $(\mathrm{m})$ from the ground level to the apex of the tassel, and the distance from ground level to the main spike.

Ten ears of corn were collected at the time of harvest for the following evaluations: h) ear diameter; i) ear length, determined from the apex to the base of the ear; $j$ ) number of rows per ear, obtained as a function of the ratio of the number of rows of grains in each ear; k) number of grains per row of ear, determined as a function of the ratio between the number of grains in each row of the ear; 1) number of grains per ear per each experimental unit, obtained by counting the number of grains in each ear; $\mathrm{m}$ ) mass of 100 grains, determined using a scale with precision $\pm 0.01 \mathrm{~g}$, at $13 \%$ (wet basis); and $\mathrm{n}$ ) grain yield, determined by collecting the plants contained in the useful area of each plot. After the mechanical track, the grains were quantified and the data units transformed to $\mathrm{kg} \mathrm{ha}^{-1}$ and corrected to $13 \%$ moisture (wet basis).

The data were subjected to analysis of variance using the F test with $\mathrm{p} \leq 0.05$. When significant differences were found, the Tukey test was used to test for differences between means, at $\mathrm{p} \leq 0.05$, using the Sisvar software package.

\section{Results ANd Discussion}

LCI was not influenced by the form of $\mathrm{N}$ application nor by inoculation with $A$. brasilense; see Table 2. In general, $\mathrm{N}$ affects the LCI because it is a component of the chlorophyll molecule. However, it is reasonable to expect that, since each treatment group received the same $\mathrm{N}$ dose, the leaf chlorophyll content would be the same. Note that the LCI values are relatively

Table1. Soil chemical attributes in the arable layer. Selvíria, MS, Brazil, 2016/2017

\begin{tabular}{|c|c|c|c|c|c|c|c|c|c|c|c|c|c|c|}
\hline P-resin & $\mathrm{S}-\mathrm{SO}_{4}$ & \multirow{2}{*}{$\begin{array}{c}\text { OM } \\
\left.(\mathrm{g} \mathrm{dm})^{-3}\right)\end{array}$} & \multirow{2}{*}{$\begin{array}{c}\mathrm{pH} \\
\mathrm{CaCl}_{2}\end{array}$} & K & Ca & $\mathrm{Mg}$ & $\mathrm{H}+\mathrm{Al}$ & Al & \multirow{2}{*}{$\begin{array}{c}\text { B } \\
\text { Hot water }\end{array}$} & Cu & $\mathrm{Fe}$ & $\mathrm{Mn}$ & $\mathrm{Zn}$ & \multirow{2}{*}{$\begin{array}{c}V \\
(\%)\end{array}$} \\
\hline (mc & & & & \multicolumn{5}{|c|}{$\left(\mathrm{mmol}_{\mathrm{c}} \mathrm{dm}^{-3}\right)$} & & \multicolumn{4}{|c|}{ DTPA } & \\
\hline 49 & 7 & 29 & 5.5 & 4.3 & 41.0 & 23.0 & 27.0 & 0.0 & 0.19 & 5.2 & 41.0 & 29.0 & 1.4 & 72 \\
\hline
\end{tabular}

OM - Organic matter; $\mathrm{V}$ - Base saturation 
Table 2. Leaf chlorophyll index $(\mathrm{LCl}), \mathrm{N}$ leaf concentration and $\mathrm{N}$ accumulation in shoot, root and grains of corn as a function of nitrogen fertilization managements inoculated or not with Azospirillum brasilense

\begin{tabular}{|c|c|c|c|c|c|}
\hline Treatments" & LCI & $\begin{array}{l}\text { N leaf concentration } \\
\left(\mathrm{g} \mathrm{kg}{ }^{-1} \text { D.M. }\right)\end{array}$ & N shoot accumulation & $\frac{\text { N root accumulation }}{\left(\mathrm{kg} \mathrm{ha}^{-1}\right)}$ & $\mathrm{N}$ grains accumulation \\
\hline \multicolumn{6}{|c|}{$\begin{array}{ll}0 \\
0\end{array}$} \\
\hline $30+150$ & $67.0 \mathrm{a}$ & 26.9 & 186.8 & 3.7 & 150.2 \\
\hline $30+75+75$ & $69.7 \mathrm{a}$ & 25.6 & 206.6 & 3.2 & 147.5 \\
\hline 180 & $67.6 \mathrm{a}$ & 25.0 & 172.0 & 4.3 & 132.5 \\
\hline $150+30$ & $68.8 \mathrm{a}$ & 26.5 & 207.5 & 4.3 & 153.1 \\
\hline L.S.D. & 3.2 & 1.5 & 54.6 & 1.4 & 20.6 \\
\hline \multicolumn{6}{|l|}{ Inoculation } \\
\hline WithA. brasilense & $68.2 \mathrm{a}$ & 25.6 & 191.2 & 3.6 & 149.1 \\
\hline WithoutA. brasilense & $68.4 \mathrm{a}$ & 26.4 & 195.3 & 4.1 & 142.5 \\
\hline L.S.D. & 1.7 & 0.8 & 28.5 & 0.8 & 10.7 \\
\hline Overall mean & 68.3 & 26.0 & 193.2 & 3.9 & 145.8 \\
\hline Standard error & 2.7 & 1.3 & 41.1 & 1.2 & 18.1 \\
\hline \multicolumn{6}{|l|}{ F test } \\
\hline Forms & $2.264^{\mathrm{ns}}$ & $5.698^{* *}$ & $1.652^{\text {ns }}$ & $2.114^{\mathrm{ns}}$ & $3.661^{*}$ \\
\hline Inoculation & $0.105^{\text {ns }}$ & $2.938^{\text {ns }}$ & $0.096^{\mathrm{ns}}$ & $1.644^{\mathrm{ns}}$ & $1.761^{\mathrm{ns}}$ \\
\hline $\mathrm{F} \times \mathrm{I}$ & $1.051^{\mathrm{ns}}$ & $3.618^{*}$ & $5.438^{*}$ & $8.429^{* *}$ & $6.927^{* *}$ \\
\hline
\end{tabular}

Means followed by the same letter in the column do not differ by the Tukey test at 0,05 probability; ** * and ns - Significant at $p<0.01,0.01<p<0.05$, and not significant, respectively; \#The treatments codes refer to: $30 \mathrm{~kg} \mathrm{ha}^{-1}$ of $\mathrm{N}$ at sowing and $150 \mathrm{~kg} \mathrm{ha}^{-1}$ in top dressing $(30+150) ; 30 \mathrm{~kg} \mathrm{ha}^{-1}$ of N in sowing and split of 2 applications of $75 \mathrm{~kg}^{-1}$ in top dressing $(30$ $+75+75) ; 180 \mathrm{~kg} \mathrm{ha}^{-1}$ of $\mathrm{N}$ at sowing $(180)$ and $150 \mathrm{~kg} \mathrm{ha}^{-1}$ of $\mathrm{N}$ at sowing and $30 \mathrm{~kg} \mathrm{ha}^{-1}$ in top dressing $(150+30)$

high even in the control crops. Costa et al. (2012) verified LCI values ranging from 39.9 to 71.2 , Kappes et al. (2013) verified LCI values ranging from 51.1 to 68.5 , and Galindo et al. (2016) verified vales ranging from 54.63 to 81.70 . Although the LCI values obtained were relatively high, it should be noted that the leaf concentration of $\mathrm{N}$ was considered slightly below adequate (27-35 $\mathrm{g} \mathrm{kg}^{-1}$; Cantarella et al., 1997) in all treatments (Table 2), which may be a feature of this simple hybrid.

The interaction between application patterns and inoculation with Azospirillum brasilense was significant for the leaf concentration of $\mathrm{N}$, and $\mathrm{N}$ accumulations in shoot, root, and grains; see Table 2. For foliar concentration of N, with application of $30 \mathrm{~kg} \mathrm{ha}^{-1}$ of $\mathrm{N}$ at sowing and two applications of $75 \mathrm{~kg} \mathrm{ha}^{-1}$ as cover without inoculation, values were higher than in the treatments inoculated with A. brasilense; see Table 3. Evaluating the inoculated treatments, application of $30 \mathrm{~kg} \mathrm{ha}^{-1}$ at sowing and application of $150 \mathrm{~kg} \mathrm{ha}^{-1}$ as a topdressing provided a leaf concentration of $\mathrm{N}$ that was greater than that seen either with a split application as cover $\left(75+75 \mathrm{~kg} \mathrm{ha}^{-1}\right)$ or with $180 \mathrm{~kg} \mathrm{ha}^{-1}$ applied at sowing; see Table 3.

Inoculation with $A$. brasilense favored the accumulation of $\mathrm{N}$ in the shoot when $\mathrm{N}$ was applied at a rate of $30 \mathrm{~kg} \mathrm{ha}^{-1}$ at sowing and two applications of $75 \mathrm{~kg} \mathrm{ha}^{-1}$ each as a topdressing. However, it hampered $\mathrm{N}$ accumulation when $180 \mathrm{~kg} \mathrm{ha}^{-1}$ were applied at sowing; see Table 3 . In each of the treatments where there was inoculation with $A$. brasilense, the split fertilization $\left(75+75 \mathrm{~kg} \mathrm{ha}^{-1}\right)$ resulted in a higher accumulation of $\mathrm{N}$ compared to the application of $180 \mathrm{~kg} \mathrm{ha}^{-1}$ at sowing; see Table 3.

As with the accumulation of $\mathrm{N}$ in the shoot, inoculation with $A$. brasilense favored the accumulation of $\mathrm{N}$ in roots when $\mathrm{N}$ was applied at a rate of $30 \mathrm{~kg} \mathrm{ha}^{-1}$ at sowing and two applications of $75 \mathrm{~kg} \mathrm{ha}^{-1}$ as topdressing, and it hampered the accumulation of $\mathrm{N}$ when $180 \mathrm{~kg} \mathrm{ha}^{-1}$ were applied at the time of sowing; see Table 3. In the absence of inoculation with $A$. brasilense, the approach of applying all of the $\mathrm{N}$ at sowing $\left(180 \mathrm{~kg} \mathrm{ha}^{-1}\right)$ and that of applying $150 \mathrm{~kg} \mathrm{ha}^{-1}$ at sowing and $30 \mathrm{~kg} \mathrm{ha}^{-1}$ as cover resulted in a higher accumulation of $\mathrm{N}$ in the roots; see Table 3 .
Table 3. Interaction between nitrogen fertilization managements and inoculation with Azospirillum brasilense in N leaf concentration and $\mathrm{N}$ shoot, root and grains accumulation

\begin{tabular}{|c|c|c|c|c|}
\hline Treatments & $30+150$ & $+75+7$ & 180 & $150+30$ \\
\hline & \multicolumn{4}{|c|}{$\mathrm{N}$ leaf concentration ( $\mathrm{g} \mathrm{kg}^{-1}$ D.M.) } \\
\hline With $A$. brasilense & $27.2 \mathrm{aA}$ & $24.5 \mathrm{bBC}$ & $24.3 \mathrm{aC}$ & $26.6 \mathrm{aAB}$ \\
\hline Without $A$. brasilense & $26.5 \mathrm{aA}$ & $26.7 \mathrm{aA}$ & $25.7 \mathrm{aA}$ & $26.5 \mathrm{aA}$ \\
\hline L.S.D. I $\times T$ & \multicolumn{4}{|c|}{1.5} \\
\hline \multirow[t]{2}{*}{ L.S.D. $T \times I$} & \multicolumn{4}{|c|}{2.1} \\
\hline & \multicolumn{4}{|c|}{ N shoot accumulation $\left(\mathrm{kg} \mathrm{ha}^{-1}\right)$} \\
\hline With $A$. brasilense & $189.3 \mathrm{aAB}$ & $245.0 \mathrm{aA}$ & $137.5 \mathrm{bB}$ & $192.8 \mathrm{aAB}$ \\
\hline Without $A$. brasilense & $184.2 \mathrm{aA}$ & $168.2 \mathrm{bA}$ & $206.6 \mathrm{aA}$ & $222.1 \mathrm{aA}$ \\
\hline L.S.D. IXT & & 56 & & \\
\hline \multirow[t]{2}{*}{ L.S.D. T×I } & & 77 & & \\
\hline & \multicolumn{4}{|c|}{$\mathrm{N}$ root accumation $\left(\mathrm{kg} \mathrm{ha}^{-1}\right)$} \\
\hline With $A$. brasilense & $3.3 \mathrm{aA}$ & $4.3 \mathrm{aA}$ & $2.8 \mathrm{bA}$ & $4.1 \mathrm{aA}$ \\
\hline Without $A$. brasilense & $4.1 \mathrm{aAB}$ & $2.2 \mathrm{bB}$ & $5.7 \mathrm{aA}$ & $4.4 \mathrm{aA}$ \\
\hline L.S.D. IXT & & 1 & & \\
\hline \multirow{2}{*}{ L.S.D. $T \times I$} & & 2. & & \\
\hline & \multicolumn{4}{|c|}{$\mathrm{N}$ grains accumulation $\left(\mathrm{kg} \mathrm{ha}^{-1}\right)$} \\
\hline With $A$. brasilense & $168.3 \mathrm{aA}$ & $152.8 \mathrm{aAB}$ & $136.1 \mathrm{aB}$ & $139.2 \mathrm{bB}$ \\
\hline Without $A$. brasilense & $132.1 \mathrm{bB}$ & $142.1 \mathrm{aAB}$ & $128.8 \mathrm{aB}$ & $167.0 \mathrm{aA}$ \\
\hline L.S.D. IXT & \multicolumn{4}{|c|}{21.5} \\
\hline L.S.D. $T \times I$ & \multicolumn{4}{|c|}{29.1} \\
\hline
\end{tabular}

Means followed by the same letter, lowercase in the column and uppercase in the row do not differ by the Tukey test at 0.05 probability

Inoculation with $A$. brasilense favored the accumulation of $\mathrm{N}$ in the grains when $\mathrm{N}$ was applied at a rate of $30 \mathrm{~kg} \mathrm{ha}^{-1}$ at sowing and $150 \mathrm{~kg} \mathrm{ha}^{-1}$ as cover. However, it hampered the accumulation of $\mathrm{N}$ when applied at a rate of $150 \mathrm{~kg} \mathrm{ha}^{-1}$ at sowing and $30 \mathrm{~kg} \mathrm{ha}^{-1}$ as cover; see Table 3 . With inoculation of the seeds with $A$. brasilense, the application of $30 \mathrm{~kg} \mathrm{ha}^{-1}$ at sowing and $150 \mathrm{~kg} \mathrm{ha}^{-1}$ as cover resulted in a higher accumulation of $\mathrm{N}$ in grains, compared to either the application of $180 \mathrm{~kg} \mathrm{ha}^{-1}$ at sowing or the application of $150 \mathrm{~kg} \mathrm{ha}^{-1}$ at sowing and $30 \mathrm{~kg} \mathrm{ha}^{-1}$ as cover. However, in the absence of inoculation, the application of $150 \mathrm{~kg} \mathrm{ha}^{-1}$ at sowing and $30 \mathrm{~kg} \mathrm{ha}^{-1}$ as cover resulted in greater accumulation of $\mathrm{N}$ in grains than did either the application of $180 \mathrm{~kg} \mathrm{ha}^{-1}$ at sowing or the application of $30 \mathrm{~kg} \mathrm{ha}^{-1}$ at sowing and $150 \mathrm{~kg} \mathrm{ha}^{-1}$ as cover; see Table 3 . 
In general, it was verified that the application of high doses of $\mathrm{N}$ at sowing ( 180 and $150 \mathrm{~kg} \mathrm{ha}^{-1}$ ) associated with inoculation with A. brasilense was detrimental to the accumulation of $\mathrm{N}$ in the shoot, roots, and grains. According to Silva et al. (2011) and Parente et al. (2015), in some crops, such as soybeans, the application of $\mathrm{N}$ in mineral form at sowing at rates in excess $20 \mathrm{~kg} \mathrm{ha}^{-1}$ can reduce the efficiency of biological nitrogen fixation (BNF).

It is probably that rates in excess of $20 \mathrm{~kg} \mathrm{ha}^{-1}$ at sowing affect the role of microorganisms, such as A. brasilense, in fixing atmospheric $\mathrm{N}$, since the use of mineral $\mathrm{N}$ in fertilizer is more readily available as a nutrient for bacteria since it does not require the breaking the triple bond in $\mathrm{N}_{2}$. Therefore, in grass crops such as corn, as well as for symbiotic crops, a high rate of application of $\mathrm{N}$ at sowing may be detrimental to BNF.

The diameter and length of the ear, plant height, and ear insertion height were not influenced by either the application of $\mathrm{N}$ or inoculation with $A$. brasilense; see Table 4.

Application of $150 \mathrm{~kg} \mathrm{ha}^{-1}$ at sowing and $30 \mathrm{~kg} \mathrm{ha}^{-1}$ as cover provided greater root development, as measured by root dry mass, compared to the application of $75 \mathrm{~kg} \mathrm{ha}^{-1}$ as topdressing; see Table 4 . For the shoot dry mass, the interaction between patterns of application and inoculation with $A$. brasilense was significant. With the application of $30 \mathrm{~kg} \mathrm{ha}^{-1}$ of $\mathrm{N}$ at sowing and two applications of $75 \mathrm{~kg} \mathrm{ha}^{-1}$ each as cover, inoculation resulted in higher values of dry mass compared to treatments not including inoculation; see Table 5. For the inoculated treatments, the application of $\mathrm{N}$ as cover provided a higher shoot dry mass compared to the application of $180 \mathrm{~kg} \mathrm{ha}^{-1}$ at sowing; see Table 5.

The higher shoot dry mass produced by treatments inoculated with doses of up to $30 \mathrm{~kg} \mathrm{ha}^{-1}$ at sowing can be explained by the results obtained for $\mathrm{N}$ accumulations in shoot, roots, and grains, because with higher accumulation of $\mathrm{N}$ in

Table 5. Interaction between nitrogen fertilization managements and inoculation with Azospirillum brasilense in corn shoot dry mass and grain yield

\begin{tabular}{|c|c|c|c|c|}
\hline Treatments & $30+150$ & $30+75+75$ & 180 & $150+30$ \\
\hline & \multicolumn{4}{|c|}{ Shoot dry mass $\left(\mathrm{kg} \mathrm{ha}^{-1}\right)$} \\
\hline With A. brasilense & $9881.0 \mathrm{aAB}$ & $11856.2 \mathrm{aA}$ & $8200.8 \mathrm{aB}$ & $9581.0 \mathrm{aAB}$ \\
\hline Without $A$. brasilense & $9731.0 \mathrm{aA}$ & $8170.8 \mathrm{bA}$ & $10051.0 \mathrm{aA}$ & $10821.1 \mathrm{aA}$ \\
\hline L.S.D. IxT & \multicolumn{4}{|c|}{2206.8} \\
\hline L.S.D. Txl & \multicolumn{4}{|c|}{2991.6} \\
\hline & \multicolumn{4}{|c|}{ Grain yield $\left(\mathrm{kg} \mathrm{ha}^{-1}\right)$} \\
\hline With $A$. brasilense & $10522.0 \mathrm{aA}$ & $9358.3 \mathrm{aAB}$ & $9001.1 \mathrm{aB}$ & $9386.0 \mathrm{aAB}$ \\
\hline Without $A$. brasilense & $8661.9 \mathrm{bB}$ & $8892.3 \mathrm{aAB}$ & $8434.4 \mathrm{aB}$ & $10033.1 \mathrm{aA}$ \\
\hline L.S.D. IxT & \multicolumn{4}{|c|}{874.2} \\
\hline L.S.D. Txl & \multicolumn{4}{|c|}{1172.2} \\
\hline
\end{tabular}

Means followed by the same letter, lowercase in the column and uppercase in the row do not differ by the Tukey test at 0,05 probability

Table 4. Shoot and root dry mass, spike diameter and lenght, plant height and height of pin insertion, stem diameter, number of rows per spike, grains per row and grains per spike, 100 grains mass and corn grain yield as a function of nitrogen fertilization managements inoculated or not with Azospirillum brasilense

\begin{tabular}{|c|c|c|c|c|c|c|}
\hline \multirow{2}{*}{ Treatments } & Shoot dry mass & Root dry mass & Spike diameter & Spike lenght & Plant height & Height of pin insertion \\
\hline & \multicolumn{2}{|c|}{$\left(\mathrm{kg} \mathrm{ha}^{-1}\right)$} & \multicolumn{2}{|c|}{$(\mathrm{cm})$} & \multicolumn{2}{|r|}{ (m) } \\
\hline $30+150$ & 9806.0 & $467.6 \mathrm{ab}$ & $5.1 \mathrm{a}$ & $16.1 \mathrm{a}$ & $2.3 \mathrm{a}$ & $1.21 \mathrm{a}$ \\
\hline $30+75+75$ & 10013.5 & $375.0 \mathrm{~b}$ & $5.0 \mathrm{a}$ & $16.0 \mathrm{a}$ & $2.3 \mathrm{a}$ & $1.25 \mathrm{a}$ \\
\hline 180 & 9125.9 & $532.6 a b$ & $5.1 \mathrm{a}$ & $15.4 \mathrm{a}$ & $2.4 \mathrm{a}$ & $1.25 \mathrm{a}$ \\
\hline $150+30$ & 10201.0 & $582.6 \mathrm{a}$ & $5.1 \mathrm{a}$ & $15.7 \mathrm{a}$ & $2.3 \mathrm{a}$ & $1.27 \mathrm{a}$ \\
\hline L.S.D. & 2115.4 & 174.9 & 0.2 & 0.9 & 0.1 & 0.08 \\
\hline \multicolumn{7}{|l|}{ Inoculation } \\
\hline WithA. brasilense & 9879.7 & $455.1 \mathrm{a}$ & $5.1 \mathrm{a}$ & $16.0 \mathrm{a}$ & $2.3 \mathrm{a}$ & $1.26 \mathrm{a}$ \\
\hline WithoutA. brasilense & 9693.5 & $523.8 \mathrm{a}$ & $5.0 \mathrm{a}$ & $15.6 \mathrm{a}$ & $2.3 \mathrm{a}$ & $1.22 \mathrm{a}$ \\
\hline L.S.D. & 1103.4 & 91.2 & 0.1 & 0.5 & 0.1 & 0.04 \\
\hline Overall mean & 9786.6 & 489.4 & 5.0 & 15.8 & 2.3 & 1.24 \\
\hline Standard error & 1620.2 & 159.9 & 0.1 & 0.7 & 0.1 & 0.06 \\
\hline \multicolumn{7}{|l|}{ F test } \\
\hline Forms & $0.831^{\mathrm{ns}}$ & $4.440^{*}$ & $0.583^{\text {ns }}$ & $1.940^{\text {ns }}$ & $1.034^{\mathrm{ns}}$ & $1.853^{\text {ns }}$ \\
\hline Inoculation & $0.131^{\mathrm{ns}}$ & $2.613^{\text {ns }}$ & $0.868^{\mathrm{ns}}$ & $2.970^{\text {ns }}$ & $0.001^{\mathrm{ns}}$ & $3.655^{\text {ns }}$ \\
\hline \multirow[t]{2}{*}{$\mathrm{FXI}$} & $5.802^{\star *}$ & $1.828^{\text {ns }}$ & $0.580^{\text {ns }}$ & $1.078^{\text {ns }}$ & $2.139^{\text {ns }}$ & $0.999^{n s}$ \\
\hline & $\begin{array}{l}\text { Stem diameter } \\
\text { (cm) }\end{array}$ & Rows per spike & Grains per row & Grains per spike & $\begin{array}{l}100 \text { grains } \\
\text { mass }(g)\end{array}$ & $\begin{array}{l}\text { Grain yield } \\
\left(\mathrm{kg} \mathrm{ha}^{-1}\right)\end{array}$ \\
\hline $30+150$ & $2.43 \mathrm{a}$ & $18.5 \mathrm{a}$ & $36.7 \mathrm{a}$ & $679.1 \mathrm{a}$ & $24.34 \mathrm{a}$ & 9591.9 \\
\hline $30+75+75$ & $2.42 \mathrm{a}$ & $18.1 \mathrm{a}$ & $34.9 \mathrm{a}$ & $628.9 \mathrm{a}$ & $24.91 \mathrm{a}$ & 9125.3 \\
\hline 180 & $2.41 \mathrm{a}$ & $18.8 \mathrm{a}$ & $36.8 \mathrm{a}$ & $692.1 \mathrm{a}$ & $24.56 \mathrm{a}$ & 8717.8 \\
\hline $150+30$ & $2.42 \mathrm{a}$ & $18.4 \mathrm{a}$ & $36.3 \mathrm{a}$ & $668.3 \mathrm{a}$ & $25.05 \mathrm{a}$ & 9709.5 \\
\hline D.M.S. & 0.02 & 1.0 & 4.9 & 94.1 & 0.88 & 828.8 \\
\hline \multicolumn{7}{|l|}{ Inoculation } \\
\hline WithA. brasilense & $2.43 \mathrm{a}$ & $18.4 \mathrm{a}$ & $37.5 \mathrm{a}$ & $689.1 \mathrm{a}$ & $24.98 \mathrm{a}$ & 9566.8 \\
\hline WithoutA. brasilense & $2.42 \mathrm{~b}$ & $18.5 \mathrm{a}$ & $34.9 \mathrm{~b}$ & 645.0a & $24.44 \mathrm{~b}$ & 9005.4 \\
\hline L.S.D. & 0.01 & 0.5 & 2.6 & 49.6 & 0.46 & 437.1 \\
\hline Overall mean & 2.42 & 18.4 & 36.2 & 667.1 & 24.71 & 9286.1 \\
\hline Standard error & 0.02 & 0.7 & 3.6 & 69.2 & 0.76 & 846.8 \\
\hline \multicolumn{7}{|l|}{ F test } \\
\hline Forms & $2.808^{\text {ns }}$ & $1.416^{\mathrm{ns}}$ & $0.510^{\text {ns }}$ & $1.306^{\mathrm{ns}}$ & $2.097^{\text {ns }}$ & $4.691^{*}$ \\
\hline Inoculation & $6.287^{\star}$ & $0.231^{\text {ns }}$ & $4.663^{*}$ & $3.425^{\mathrm{ns}}$ & $5.800^{*}$ & $7.135^{*}$ \\
\hline FXI & $0.293^{\text {ns }}$ & $1.120^{\mathrm{ns}}$ & $0.506^{\mathrm{ns}}$ & $0.122^{\text {ns }}$ & $0.863^{\text {ns }}$ & $5.953^{* \star}$ \\
\hline
\end{tabular}

Means followed by the same letter in the column do not differ by the Tukey test at 0,05 probability; $* *$ * and ns - Significant at $p<0.01,0.01<p<0.05$, and not significant, respectively; \#The treatments codes refer to: $30 \mathrm{~kg} \mathrm{ha}^{-1}$ of $\mathrm{N}$ at sowing and $150 \mathrm{~kg} \mathrm{ha}^{-1}$ in top dressing $(30+150) ; 30 \mathrm{~kg} \mathrm{ha}^{-1}$ of N in sowing and split of 2 applications of $75 \mathrm{~kg}^{-1}$ in top dressing (30 $+75+75) ; 180 \mathrm{~kg} \mathrm{ha}^{-1}$ of $\mathrm{N}$ at sowing (180) and $150 \mathrm{~kg} \mathrm{ha}^{-1}$ of $\mathrm{N}$ at sowing and $30 \mathrm{~kg} \mathrm{ha}^{-1}$ in top dressing $(150+30)$ 
the reproductive organs, the corn plant can use the nutrient to reach its potential for growth and development in the shoot, which reflects on the grain yield, as shown in Table 4.

The application of high doses of $\mathrm{N}$ at sowing favored the production of root dry mass; however, according to Queiroz et al. (2011), when the application of $\mathrm{N}$ exceeds the needs of the corn plant during the early stages of development, the loss of $\mathrm{N}$ due to volatilization of ammonia and the greater immobilization of mineral $\mathrm{N}$ due to microorganisms and the decomposition of vegetal residues present in the soil, the efficiency of nitrogen fertilization can be reduced. In addition, according to Rezende et al. (2015), the absence of adequate $\mathrm{N}$ availability in the period between the V4 and V6 stages may lead to less development of the aerial part and spike, which negatively affects the grain filling and culminated in a lower grain yield. This may explain why the application of a high dose (180 and $\left.150 \mathrm{~kg} \mathrm{ha}^{-1}\right)$ at sowing and without additional application as cover, and with the application of only $30 \mathrm{~kg} \mathrm{ha}^{-1}$, results in less production of shoot dry mass, although this favors root production.

The amount and timing of $\mathrm{N}$ application had no effect on stem diameter, number of rows per spike, grains per row, grains per spike, or the mass of 100 grains; see Table 4 . Following inoculation of seeds with $A$. brasilense, there was an increase in the stem diameter, the grains per row, and the mass of 100 grains; the increase in grains per row was 7.1, the increase in grains per spike was 6.5 , and the increase in mass of 100 grains was $2.2 \%$. This resulted in an increase of grain yield of $561.45 \mathrm{~kg} \mathrm{ha}^{-1}$, equivalent to approximately 9.4 sacks of $60 \mathrm{~kg} \mathrm{ha}^{-1}$, which is an increase of productivity of $5.9 \%$; see Table 4 .

Positive results with the use of Azospirillum were also reported by Kappes et al. (2013), working with doses of $\mathrm{N}$ and inoculation with $A$. brasilense in corn in the first harvest. They found that inoculation resulted in a $9.4 \%$ increase in grain yield. Similar results were obtained by Novalkowiski et al. (2011), where corn yields were higher with inoculation of $A$. brasilense when compared to the control, even with an increase in the amount of $\mathrm{N}$ applied. Hungria et al. (2010) also obtained increases in corn yield, and depending on the strain of $A$. brasilense evaluated, the increase in productivity was of the order of 24 to $30 \%$, corresponding to 662 to $823 \mathrm{~kg} \mathrm{ha}^{-1}$.

These increases are commonly attributed to root growth promotion, accomplished by phytohormones produced by the bacterium, with an emphasis on indole acetic acid, gibberellins, and cytokinins (Tien et al., 1979). Moreover, it is inferred that the application of Azospirillum is also responsible for higher rates of absorption of water and minerals by the plant (Dardanelli et al., 2008) and higher tolerance to abiotic stresses, such as drought and salinity (Cassán et al., 2009; Zawonski et al., 2011). The relationship between different soil microorganisms and the role of metabolites secreted by them on the growth of the surrounding microbial species and plants has been the subject of numerous studies (Marks et al., 2015; Fukami et al., 2016, 2017), and according to Bashan \& Bashan (2010), due to the wide array of mechanisms proposed for stimulation of plant growth by Azospirillum spp., probably this bacteria promotes multiple mechanisms that might act either cumulatively or sequentially.

Despite the increase in corn grain yield, the effects on grasses are variable, and according to Novakowiski et al. (2011), it is thus difficult to specify an accurate recommendation for the use of these inoculants in corn crops. It is of fundamental importance to take into account that the interaction between the particular genotype of each plant with the efficient strains of bacteria is a key factor in the success of BNF (Lana et al., 2012).

The interaction between the various patterns of $\mathrm{N}$ application and inoculation with $A$. brasilense was significant with respect to the grain yield. Inoculation increased grain yield when $30 \mathrm{~kg} \mathrm{ha}^{-1}$ of $\mathrm{N}$ were applied at sowing, followed by $150 \mathrm{~kg} \mathrm{ha}^{-1}$ as a topdressing; see Table 5 . When evaluating the inoculated treatments, it was observed that the application of $30 \mathrm{~kg} \mathrm{ha}^{-1}$ of $\mathrm{N}$ at sowing and $150 \mathrm{~kg} \mathrm{ha}^{-1}$ as topdressing provided a higher grain yield compared to the application of $180 \mathrm{~kg} \mathrm{ha}^{-1}$ at sowing. In the absence of inoculation, the application of $150 \mathrm{~kg} \mathrm{ha}^{-1}$ of $\mathrm{N}$ at sowing and $30 \mathrm{~kg} \mathrm{ha}^{-1}$ as topdressing provided a higher yield compared to either the application of $30 \mathrm{~kg} \mathrm{ha}^{-1}$ of $\mathrm{N}$ at sowing and $150 \mathrm{~kg} \mathrm{ha}^{-1}$ as topdressing or to $180 \mathrm{~kg} \mathrm{ha}^{-1}$ at sowing; see Table 5 .

For grain yield, the interaction between patterns of $\mathrm{N}$ application and inoculation is similar to that observed for $\mathrm{N}$ accumulations in shoot, roots, grains, and shoot dry mass, that is, the application of high doses of $\mathrm{N}$ at sowing following inoculation with $A$. brasilense resulted in a reduction in grain yield. This demonstrates that the application of $\mathrm{N}$ following inoculation with $A$. brasilense has better results when less $\mathrm{N}$ is applied at the time of sowing, that is, up to $30 \mathrm{~kg} \mathrm{ha}^{-1}$, and when there is a topdressing of $\mathrm{N}$ between the vegetative stages V4 and V6.

\section{Conclusions}

1. The application pattern of $\mathrm{N}$ does not influence LCI, foliar concentration of $\mathrm{N}$, accumulation of $\mathrm{N}$ in shoot, roots, and grains, components production, or corn grain yield.

2. Inoculation with Azospirillum brasilense positively influences stem diameter, number of grains per row, and mass of 100 grains, which reflects an increase in grain yield.

3. The application of higher doses of nitrogen at sowing following inoculation with Azospirillum brasilense negatively affects the accumulation of $\mathrm{N}$ in shoot, roots, and grains, and shoot dry mass, and thus reduces the grain yield.

4. Inoculation with Azospirillum brasilense is recommended with the application of $30 \mathrm{~kg} \mathrm{ha}^{-1}$ of $\mathrm{N}$ at the time of sowing, and between the inoculated V4 to V6 vegetative stages, the application of a single topdressing of $150 \mathrm{~kg} \mathrm{ha}^{-1}$ or two applications of $75 \mathrm{~kg} \mathrm{ha}^{-1}$ each, in order to achieve better nutrition, development, and yield of irrigated corn.

\section{Literature Cited}

Bashan, Y.; Bashan, L. E. de. How the plant growth-promoting bacterium Azospirillum promotes plant growth: A critical assessment. Advances in Agronomy, v.108, p.77-136, 2010. https:// doi.org/10.1016/S0065-2113(10)08002-8

Cantarella, H.; Raij, B. van; Camargo, C. E. O. Cereals. In: Raij, B. van; Cantarella, H.; Quaggio, J. A.; Furlani, A. M. C. (eds.). Liming and fertilization recommendations for the State of São Paulo. Campinas: Instituto Agronômico de Campinas, 1997. 285p. Boletim Técnico, 100 
Cassán, F.; Maiale, S.; Masciarelli, O.; Vidal, A.; Luna, V.; Ruiz, O. Cadaverine production by Azospirillum brasilense and its possible role in plant growth promotion and osmotic stress mitigation. European Journal of Soil Biology, v.45, p.12-19, 2009. https://doi. org/10.1016/j.ejsobi.2008.08.003

Costa, N. R.; Andreotti, M.; Gameiro, R. de A.; Pariz, C. M.; Buzetti, S.; Lopes, K. S. M. Nitrogen fertilization in the intercropping of corn with two Brachiaria species in a no-tillage system. Pesquisa Agropecuária Brasileira, v.47, p.1038-1047, 2012. https://doi. org/10.1590/S0100-204X2012000800003

Dardanelli, M. S.; Córdoba, F. J. F. de; Espuny, M. R.; Carvajal, M. A. R.; Díaz, M. E. S.; Serrano, A. M. G.; Okon, Y.; Megías, M. Effect of Azospirillum brasilense coinoculated with Rhizobium on Phaseolus vulgaris flavonoids and nod factor production under salt stress. Soil Biology and Biochemistry, v.40, p.2713-2721, 2008. https:// doi.org/10.1016/j.soilbio.2008.06.016

Díaz-Zorita, M.; Fernandez-Canigia, M. V. Field performance of a liquid formulation of Azospirillum brasilense on dryland wheat productivity. European Journal of Soil Biology, v.45, p.3-11, 2009. https://doi.org/10.1016/j.ejsobi.2008.07.001

EMBRAPA - Empresa Brasileira de Pesquisa Agropecuária. Brazilian system of soil classification. 3.ed. Rio de Janeiro: Embrapa Solos, 2013. 353p.

Espindula, M. C.; Rocha, V. S.; Souza, M. A. D. de; Campanharo, M.; Pimentel, A. J. B. Urease inhibitor (NBPT) and efficiency of single or split application of urea in wheat crop. Revista Ceres, v.61, p.273-79, 2014. https://doi.org/10.1590/S0034737X2014000200016

Fukami, J.; Nogueira, M. A.; Araujo, R. S.; Hungria, M. Accessing inoculation methods of maize and wheat with Azospirillum brasilense. AMB Express, v.6, p.3-16, 2016. https://doi. org/10.1186/s13568-015-0171-y

Fukami, J.; Ollero, F. J.; Megías, M.; Hungria, M. Phytohormones and induction of plant-stress tolerance and defense genes by seed and foliar inoculation with Azospirillum brasilense cells and metabolites promote maize growth. AMB Express, v.7, p.153-163, 2017. https://doi.org/10.1186/s13568-017-0453-7

Galindo, F. S.; Teixeira Filho, M. C. M.; Buzetti, S.; Santini, J. M. K.; Alves, C. J.; Nogueira, L. M.; Ludkiewicz, M. G. Z.; Andreotti, M.; Bellotte, J. L. M. Corn yield and foliar diagnosis affected by nitrogen fertilization and inoculation with Azospirillum brasilense. Revista Brasileira de Ciência do Solo, v.40, p.1-18, 2016. https:// doi.org/10.1590/18069657rbcs20150364

Hartmann, A.; Bashan, Y. Ecology and application of Azospirillum and other plant growth-promoting bacteria (PGPB). European Journal of Soil Biology, v.45, p.1-2, 2009. https://doi.org/10.1016/j. ejsobi.2008.11.004

Hungria, M.; Campo, R. J.; Souza, S. E. M.; Pedrosa, F. O. Inoculation with selected strains of Azospirillum brasilense and A. lipoferum improves yields of maize and wheat in Brazil. Plant and Soil, v.331, p.413-425, 2010. https://doi.org/10.1007/s11104-009-0262-0

Kappes, C.; Arf, O.; Andrade, J. A. da C. Effects of cover crops, soil management and nitrogen rates on nutritional and agronomic attributes of maize. Revista Brasileira de Ciência do Solo, v.37, p.1322-1333, 2013. https://doi.org/10.1590/S010006832013000500021

Lana, M. do C.; Dartora, J.; Marini, D.; Hann, J. E. H. Inoculation with Azospirillum, associated with nitrogen fertilization in maize. Revista Ceres, v.59, p.399-405, 2012. https://doi.org/10.1590/ S0034-737X2012000300016
Marks, B. B.; Megías, M.; Ollero, F. J.; Nogueira, M. A.; Araujo, R. S.; Hungria, M. Maize growth promotion by inoculation with Azospirillum brasilense and metabolites of Rhizobium tropici enriched on lipo-chitooligosaccharides (LCOs). AMB Express, v.5, p.71-82, 2015. https://doi.org/10.1186/s13568-015-0154-Z

Novakowiski, J. H.; Sandini, I. E.; Falbo, M. K.; Moraes, A. de; Novakowiski, J. H.; Cheng, N. C. Residual effect of nitrogen fertilization and Azospirillum brasilense inoculation in the maize culture. Semina: Ciências Agrárias, v.32, p.1687-1698, 2011. https://doi.org/10.5433/1679-0359.2011v32n4Sup1p1687

Nunes, P. H. M. P.; Aquino, L. A.; Santos, L. P. D. dos; Xavier, F. O.; Dezordi, L. R.; Assunção, N. S. Yield of the irrigated wheat crop subjected to nitrogen application and to inoculation with Azospirillum brasilense. Revista Brasileira de Ciência do Solo, v.39, p.174-182, 2015. https://doi.org/10.1590/01000683rbcs20150354

Parente, T. de L.; Lazarini, E.; Caioni, S.; Pivetta, R. S.; Souza, L. G. M. de; Bossolani, J. W. Nitrogen fertilization at soybean genotypes associated with inoculation in no-tillage in the Savannah. Revista Brasileira de Ciências Agrárias, v.10, p.249-255, 2015. https://doi. org/10.5039/agraria.v10i2a5320

Queiroz, A. M. de; Souza, C. H. E. de; Machado, V. J.; Lana, R. M. Q.; Korndorfer, G. H.; Silva, A. D. Evaluation of different sources and rates of nitrogen fertilization in maize (Zea mays L.) Revista Brasileira de Milho e Sorgo, v.10, p.257-266, 2011.

Raij, B. van; Andrade, J. C.; Cantarella, H.; Quaggio, J. A. Análise química para avaliação da fertilidade de solos tropicais. Campinas: Instituto Agronômico de Campinas, 2001. 285p.

Rezende, W. S.; Brito, C. H. de; Brandão, A. F.; Franco, C. J. F.; Ferreira, M. V.; Ferreira, A. de S. Grain development and yield in maize subjected to defoliation levels. Pesquisa Agropecuária Brasileira, v.50, p.203209, 2015. https://doi.org/10.1590/S0100-204X2015000300003

Santos, M. M.; Galvão, J. C. C.; Silva, I. R.; Miranda, G. V.; Finger, F. L. Nitrogen sidedressing and molybdenum application to untilled corn and nitrogen $\left({ }^{15} \mathrm{~N}\right)$ allocation in the plant. Revista Brasileira de Ciência do Solo, v.34, p.1185-1194, 2010. https://doi. org/10.1590/S0100-06832010000400018

Silva, A. F. da; Carvalho, M. A. C. de; Schoninger, E. L.; Monteiro, S.; Caione, G.; Santos, P. A. Doses of inoculant and nitrogen at sowing of soybean in first cultivation area. Bioscience Journal, v.27, p.404-412, 2011.

Teixeira Filho, M. C. M.; Buzetti, S.; Andreotti, M.; Arf, O.; Benett, C. G. $\mathrm{S}$. Doses, sources and time of nitrogen application on irrigated wheat under no-tillage. Pesquisa Agropecuária Brasileira, v.45, p.797-804, 2010. https://doi.org/10.1590/S0100-204X2010000800004

Teixeira Filho, M. C. M.; Buzetti, S.; Andreotti, M.; Benett, C. G. S.; Arf, O.; Sá, M. E. de. Wheat nitrogen fertilization under no till on the low altitude Brazilian Cerrado. Journal of Plant Nutrition, v.37, p.1732-48, 2014. https://doi.org/10.1080/01904167.2014.889150

Tien, T. M.; Gaskins, M. H.; Hubbell, D. H. Plant growth substances produced by Azospirillum brasilense and their effect on the growth of pearl millet (Pennisetum americanum L.). Applied and Environmental Microbiology, v.37, p.1016-1029, 1979.

Xu, G.; Fan, X.; Miller, A. J. Plant nitrogen assimilation and use efficiency. Annual Review of Plant Biology, v.63, p.153-182, 2012. https://doi.org/10.1146/annurev-arplant-042811-105532

Zawonski, M. S.; Ameneiros, M.; Benavides, M. P.; Vázquez, S.; Groppa, M. D. Response to saline stress and aquaporin expression in Azospirillum-inoculated barley seedlings. Applied Microbiology and Biotechnology, v.90, p.1389-1397, 2011. https:// doi.org/10.1007/s00253-011-3162-1 